\section{Growth and Boron Uptake of Five Pecan Cultivar Seedlings}

\author{
G.A. Picchioni ${ }^{1}$ and S. Miyamoto ${ }^{2}$ \\ Texas A\&M University Agricultural Research and Extension Center, \\ 1380 A\&M Circle, El Paso, TX 79927
}

\author{
J.B. Storey ${ }^{3}$ \\ Department of Horticultural Sciences, Texas A\&M University, College \\ Station, TX 77843-2133
}

Additional index words. boron toxicity, irrigation water quality, salinity, Carya illinoensis

\begin{abstract}
Growth and B uptake of five pecan [Carya illinoensis (Wangenh.) C. Koch] seedling cultivars were evaluated in two greenhouse experiments. Seedlings were exposed for 7 to 8 months to various B-containing irrigation solutions. In one study, the growth of 'Apache', 'Riverside', and 'Burkett' seedlings declined significantly with a 5.0-mg B/liter application that provided $12.3 \mathrm{mg} \mathrm{B} /$ liter in the soil saturation extract. In the second study, B application of $2.5 \mathrm{mg}^{-1} 1 \mathrm{iter}^{-1}\left(6.4 \mathrm{mg}^{-1 i t e r^{-1}}\right.$ in the saturation extract) reduced growth of 'Western' and Wichita' seedlings. Seedling sources differed in susceptibility to B applications. 'Apache' and 'Wichita' seedlings were the more sensitive cultivars in the experiments. Leaf $B$ concentrations increased linearly with concentrations in the saturation extract $(r=0.96$ to 0.99$)$, but did not depend on the cultivar. Boron toxicity (leaf interveinal chlorosis and tip necrosis) occurred within several weeks following $B$ application of 1.25 to $2.5 \mathrm{mg}^{-1 i t e r}{ }^{-1}\left(2.8\right.$ to $6.6 \mathrm{mg}^{\circ} \cdot \operatorname{liter}^{-1}$ in the saturation extract, depending on cultivar). Three months later, chlorotic areas became necrotic inleaves containing $>900 \mathrm{mg} \mathrm{B} / \mathrm{kg}$ dry weight. Severe necrosis and some defoliation occurred when $B$ concentrations were increased further. Leaves with no injury contained $\leq 325 \mathrm{mg} \mathrm{B} / \mathrm{kg}$.
\end{abstract}

Boron, an essential element, is recognized to cause toxic effects to many crops, including pecan. Sparks and Payne (1976) reported that application of sodium borate (to alleviate B deficiency) caused toxic symptoms on leaves of 'Cherokee' (from 1-year-old scion) at application rates of $50 \mathrm{~g} \mathrm{~B}$ or more per tree. The level of $B$ in soils that causes foliar toxicity in pecan has, however, not been adequately studied. Eaton (1935) considered, based on the visual ranking of leaf injury symptoms of many crops grown in sand culture, that pecan (cultivar unspecified) is on the border of sensitive to semitolerant crops. At the time, the threshold concentration that causes toxicity was left blank for future studies. Wilcox (1960) then

Received for publication 16 May 1990. Contribution from the Texas Agricultural Experiment Station and supported in part by the Expanded Research Area fund of the Experiment Station. The cost of publishing this paper was defrayed in part by the payment of page charges. Under postal regulations, this paper therefore must be hereby marked advertisement solely to indicate this fact. ${ }^{1}$ Former graduate research assistant and Thomas B. Slick Fellow. Present address: Dept. of Pomology, Univ. of California, Davis, CA 95616. ${ }^{2}$ Professor of Soil and Water Science.

${ }^{3}$ Professor of Horticultural Sciences. inserted the threshold concentration in irrigation water with little explanation $(1 \mathrm{mg} \mathrm{B} /$ liter), but the same threshold concentration was later interpreted by Bernstein (1974) to be the concentration in the soil saturation extract. There seem to be no reliable data to support either guideline for pecans. This study evaluated growth and B uptake responses of seedlings from selected cultivars used by the irrigated pecan industry.

General methods. Two experiments were initiated at El Paso. Experiment 1 included 'Apache', 'Riverside', and 'Burkett' seedlings, while 'Western' and 'Wichita' seedlings were tested in Expt. 2. Pecan nuts were stratified for 10 weeks in perlite at $3 \mathrm{C}$, sprouted in shallow trays containing vermiculite, then planted in 20-liter plastic pots. The pots contained the A horizon of Hueco sandy loam (calcareous, coarse silty, mixed, thermic, Petrocalcic Paleargid). The lower half of the pots was filled with the soil pretreated with dissolved boric acid in amounts to satisfy the sorption deficit according to the method of Ryan et al. (1977).

One month after planting, seedlings were thinned to an equal size, having four to five simple leaves and trunk heights between 18 and $22 \mathrm{~cm}$. After thinning, each pot contained two seedlings of each cultivar. Boron

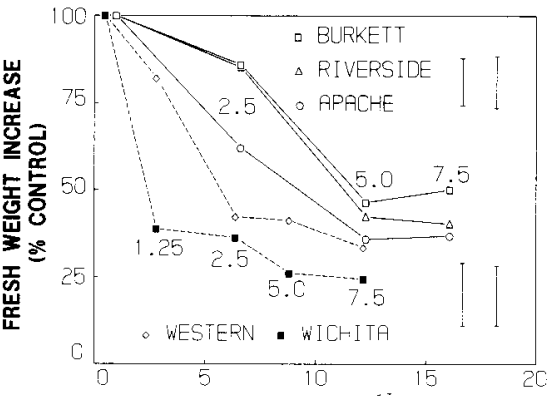

B IN SATURATION EXTRACT (mg.liter ${ }^{-1}$ )

Fig. 1. Trunk + root fresh weight increase of B-treated pecan seedling cultivars. Data for Expt. 1 ('Burkett', 'Riverside', and 'Apache'; solid lines) are growth increments from 25 July 1986 to 15 June 1987; data for Expt. 2 ('Western" and 'Wichita'; dashed lines) are from 1 Nov. 1987 to 7 July 1988 . Left bars are the LSD (5\%) between B levels; right bars within B levels. Boron-containing irrigation solutions are indicated (in $\mathrm{mg} \cdot \mathrm{liter}^{-1}$ ) by points, each representing the mean of five replications.

treatments (supplied as boric acid in tap water) with 0.50 -strength Hoagland nutrient solution no. 1 without B (Hoagland and Arnon, $1950)$ contained trace $(<0.2 \mathrm{mg} \mathrm{B} /$ liter in tap water), 2.5, 5.0, or $7.5 \mathrm{mg} \mathrm{B/liter.} \mathrm{The}$ pots were watered in an amount to control the leaching fraction between 0.45 and 0.55 (drainage per application volume) when the soil water storage, measured gravimetrically, was depleted to half of the water-holding capacity $\left(0.30 \mathrm{~m}^{3} \cdot \mathrm{m}^{-3}\right)$. The greenhouse was maintained between 16 and $32 \mathrm{C}$.

Soils were sampled midway and at the end of B treatment periods and analyzed for B in the saturation extract (U.S. Salinity Laboratory Staff, 1954) using a plasma emission spectrometer (Applied Research Laboratories, Sunland, Calif.). The average of the two values was used to express B concentrations in the soil.

Entire seedlings were harvested, roots were washed free of soil, and trunk + root fresh weight was recorded. The growth of trunk + roots (fresh weight increase) was computed as the fresh weight at harvest minus the fresh weight when B treatments began (the latter was estimated as the average fresh weight of five seedlings per cultivar). All leaves (fully expanded with petioles) were rinsed briefly with distilled water, dried at $60 \mathrm{C}$ for $24 \mathrm{~h}$, and ground in a Wiley mill to pass a 40-mesh screen. Ground tissue was ignited in a muffle furnace at 550C for 12 $\mathrm{h}$, extracted for B (Hatcher and Wilcox, 1950), and analyzed for B as described for soils.

Both experiments were split plots, with B treatments as the main plot and seed source (cultivar) as subplot (Little and Hills, 1978). The average value of two seedlings per pot 
Table 1. Cumulative shoot elongation (17 Feb. to 7 July 1988) of 'Western' and 'Wichita' pecan seedlings in relation to applied B and that in the soil saturation extract (SSE).

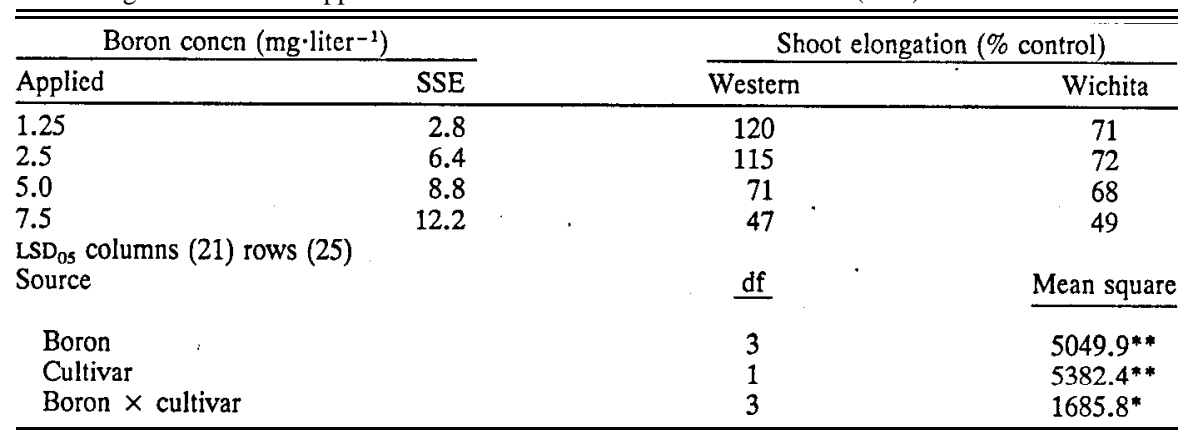

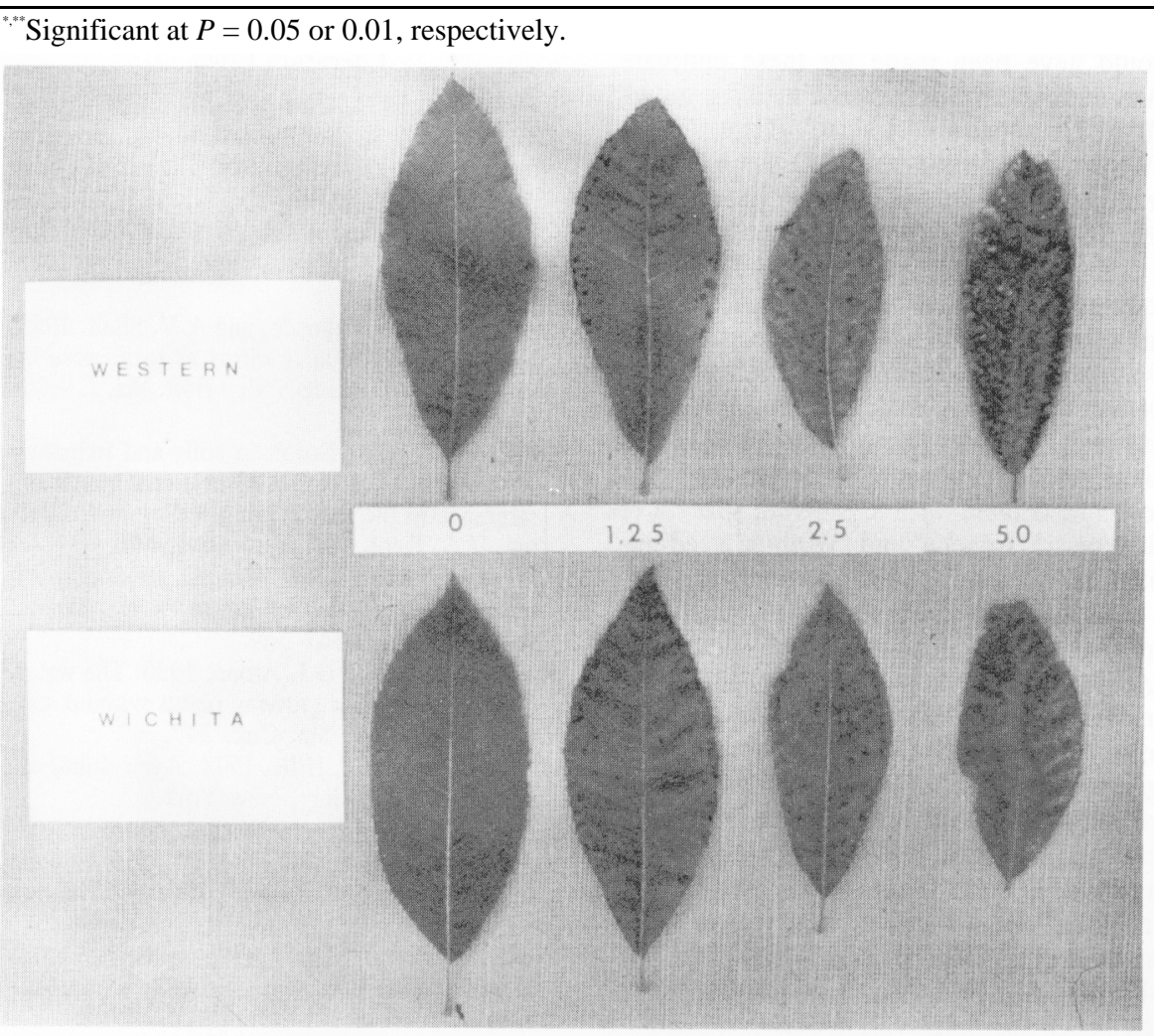

Fig. 2. Boron-induced leaf necrosis and size reduction of 'Western' and 'Wichita' pecan seedlings. Boron concentrations are listed in $\mathrm{mg} \cdot$.liter' in irrigation solutions. The respective soil saturation extract concentrations were $0.5,2.8,6.4$, and $8.8 \mathrm{mg} \cdot \mathrm{liter}^{-1},$. Average leaf area of controls [0 or trace B) ranged from 30 to $40 \mathrm{~cm}^{2}$.

was used as the statistical unit with five replications.

'Apache' 'Riverside' and 'Burkett' (Expt. 1). Seedlings were planted in pots 27 June 1986 , and B treatments began 25 July. By 31 Oct., control trunk height increased by $\approx 13 \%$, and the seedlings were moved to an unheated shadehouse until 31 Jan. 1987. With our conditions, pecan seedlings had improved vigor following a chilling period $(\approx 3$ months providing 500 to $1000 \mathrm{~h}$ below $5 \mathrm{C}$ ) compared to continuous culture during decreasing natural photoperiod. However, poor vigor was not observed during $\mathrm{B}$ treatments under increasing natural photoperiod (see Expt. 2).

Seedlings completely defoliated during the dormant period. On 1 Feb., the seedlings were returned to the greenhouse and B treatments continued until 15 June (4\% months), providing a 71/2-month net treatment period. All leaves that had not fallen were collected and analyzed for B. Leaves injured by B sured. The net treatment duration was 8 months.

Boron in soil saturation extract. Boron concentrations in the saturation extract were similar in Expts. 1 and 2 for trace (control) and $2.5 \mathrm{mg} \cdot$ liter $^{-1}$ applications (Fig. 1). However, the saturation extract concentrations for the 5.0 and $7.5 \mathrm{mg} \cdot$ liter $^{-1}$ treatments averaged 26\% less in Expt. 2. This difference may be attributed to variation in leaching fractions between experiments.

Seedling growth. Boron concentration and cultivar significantly affected increases in seedling fresh weight (Fig. 1). The growth of 'Apache' trunk + roots dropped sharply with $6.6 \mathrm{mg} \mathrm{B} /$ liter in the saturation extract. Trunk + root growth of 'Riverside' and 'Burkett' seedlings decreased only $14 \%$ with this B concentration, but was significantly reduced at $12.3 \mathrm{mg} \cdot \operatorname{liter}^{-1}$ in the saturation extract.

Trunk + root growth of 'Wichita' seedlings was less than half of controls with 2.8 $\mathrm{mg} \mathrm{B} /$ liter in the saturation extract (Fig. 1). 'Western' seedling growth was greater than that of 'Wichita' seedlings with this B concentration, and did not decrease significantly until B was raised to $6.4 \mathrm{mg} \cdot \mathrm{liter}^{-1}$ in the saturation extract. In Expt. 2 , the $\mathrm{B} \times$ cultivar interaction was significant.

Boron also reduced shoot elongation of 'Western' and 'Wichita' seedlings, which again depended on the cultivar (Table 1). Shoot growth of 'Wichita' was decreased by almost $30 \%$ with soil B levels of 2.8 and 6.4 mg.liter ${ }^{-1}$, whereas that of 'Western' did not decrease until B levels rose above 6.4 $\mathrm{mg} \cdot$ liter $^{-1}$. The percentage of 'Western' and 'Wichita' seedlings that produced new shoots from axillary and terminal buds decreased with increasing $\mathrm{B}$ concentration (combined averages of $96 \%, 61 \%$, and $47 \%$ in trace, 2.8 , and $6.4 \mathrm{mg} \cdot$ liter $^{-1}$ soil concentrations, respectively). With higher B levels, all regrowth originated from roots, indicating a toxic effect of B on trunk vegetative buds.

Boron toxicity symptoms. Injury appeared within 2 to 3 weeks of treatment on fully expanded leaves of 'Apache', 'Riverside', and 'Burkett' seedlings exposed to $6.6 \mathrm{mg}$ $\mathrm{B} /$ liter and higher in the saturation extract. Symptoms began as interveinal chlorosis and tip necrosis on older leaves (lower one-third of stem axes), followed by necrosis in marginal and interveinal regions $\approx 3$ months later. Subsequently, extensive necrosis and drop of the older leaves occurred with concentrations of 12.3 and $16.1 \mathrm{mg} \cdot$ liter $^{-1}$.

Boron injury was also observed with 'Western' and 'Wichita' seedlings, even with $2.8 \mathrm{mg} \mathrm{B} /$ liter in the saturation extract (1 .25 mg.liter ${ }^{-1}$ application; Fig. 2). At this concentration, however, the youngest leaves were uninjured. Chlorosis, necrosis, and leaf cupping occurred with $6.4 \mathrm{mg} \mathrm{B} /$ liter, while 8.8 $\mathrm{mg} \cdot \mathrm{liter}^{-1}$ caused severe necrosis. With 12.3 $\mathrm{mg} \mathrm{B/liter,} \mathrm{leaves} \mathrm{were} \mathrm{much} \mathrm{smaller,} \mathrm{with}$ distorted margins. Soil B concentrations $\geq 6.4$ $\mathrm{mg} \cdot \mathrm{liter}^{-1}$. reduced leaf area by at least $29 \%$ (Fig. 2), but there were no cultivar differences in this response (data not shown).

Tissue B concentration. Boron concentra- 

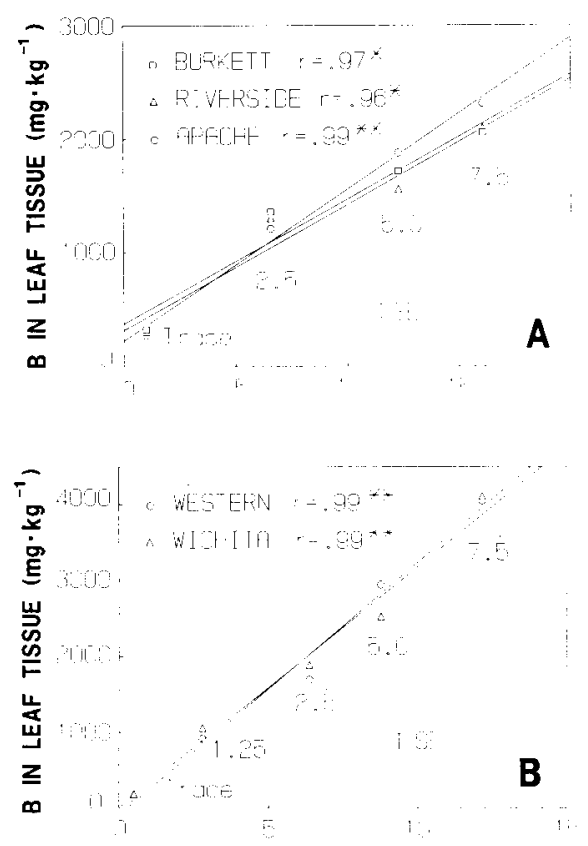

B IN SATURATION EXTRACT (mg $\cdot$ liter $^{-1}$ )

Fig.3. Leaf B concentrations (dry-weight basis) of pecan seedling cultivars in Expt. 1(A) and Expt. 2 (B). The standard error (SE) is pooled for within and between B level comparisons. Significance of $\mathrm{r}$ at $5 \%(*)$ or $1 \%(* *)$ levels. Irrigation solutions and replications as in Fig. 1 .

tion in leaf tissue increased linearly with that in the saturation extract. Leaves of 'Apache', 'Riverside', and 'Burkett' seedlings with no visible injury contained $<325 \mathrm{mg} \mathrm{B} / \mathrm{kg}$ dry weight (Fig. 3A). There were no cultivar effects on leaf B concentrations, although 'Apache' seedlings tended to contain more B than 'Riverside' and 'Burkett' seedlings at the two highest levels. Boron concentrations in leaves of 'Western' and 'Wichita' seedlings were markedly similar despite seedling growth differences, and also increased with B application (Fig. 3B).

Boron concentrations in roots and trunks of Expt. 1 seedling cultivars ranged from 140 to 190 and 180 to $320 \mathrm{mg} \cdot \mathrm{kg}^{-1}$ dry weight, respectively, compared to $>1500$ $\mathrm{mg} \cdot \mathrm{kg}^{-1}$ for leaves at the $12.3 \mathrm{mg} \mathrm{B} / \mathrm{liter}$ soil concentration ( $5 \mathrm{mg} \cdot \mathrm{liter}^{-1}$ application). On a quantity basis, $45 \%$ to $60 \%$ of total seedling B was present in leaves, $20 \%$ to
$35 \%$ in roots, and $10 \%$ to $20 \%$ in trunks, with no differences among the cultivars.

We have shown that low concentrations of B (1.25 mg.liter ${ }^{-1}$ in irrigation water, or $\approx 3 \mathrm{mg} \cdot$ liter $^{-1}$ in the saturation extract) can cause foliar toxicity in pecan. This finding is consistent with the prediction of Wilcox (1960). However, no toxicity occurred with a saturation extract level of $1 \mathrm{mg} \cdot$ liter $^{-1}$ (Expt. 1), which is the foliar toxicity guideline given by Bernstein (1974). If more observations in the lower concentration range $(<1.25$ $\mathrm{mg} \cdot$ liter $^{-1}$ application) were included, an estimation of the minimal $\mathrm{B}$ concentration needed without seedling growth reduction could have been made for these cultivars. Any addition of B suppressed seedling growth (Fig. 1), although 'Apache' (Expt. 1) and 'Wichita' seedlings (Expt. 2) seemed to be more sensitive to high $\mathrm{B}$ than seedlings of the other cultivars (Fig. 1, Table 1).

Leaf injury symptoms observed in pecan leaves (Fig. 2) are different from chloride injury, which starts as leaf tip necrosis, then develops to marginal necrosis. Boron injury begins as tip burn, interveinal chlorosis, and cupping of leaves before widespread necrosis. The development of leaf injury appeared to be associated with significant growth reduction of 'Apache' and 'Wichita' seedings, but not necessarily of the others.

Blackmon and Winsor (1946) found that marginal leaf necrosis of 17-year-old 'Stuart' trees occurred when leaves accumulated $\approx 550$ to $700 \mathrm{mg} \mathrm{B} / \mathrm{kg}$ dry weight (1 to 2 months after B application). Marginal necrosis began to appear at $\approx 500 \mathrm{mg} \cdot \mathrm{kg}^{-1}$ on several seedlings of our study, but we recorded generally higher toxic leaf B concentrations. On average, B-affected leaves contained a minimum of $\approx 900 \mathrm{mg} \cdot \mathrm{kg}^{-1}$, whether after $31 / 2$ months (Fig. 3B) or $1 \frac{1}{2}$ months (data not shown). Although leaf B concentrations of the pecan seedlings varied between Expts. 1 and 2, the close correlations (Fig. 3) indicate that pecan seedling B status can be estimated using saturation extract B or leaf B measurements in the same experimental conditions.

Despite some growth differences among 'Apache', 'Riverside', and 'Burkett' seedlings, B uptake characteristics were similar. Several authors suggest that B uptake is chiefly passive and movement to leaves is driven by transpiration (Oertli and Kohl, 1961;
Raven, 1980). If there were a pecan rootstock having low B uptake characteristics, leaf injuries of pecan cultivars could be reduced. Such a possibility was demonstrated for grapefruit by Cooper et al. (1955). However, this possibility does not seem to exist in these particular seedling cultivars, which are commonly used as rootstock in the irrigated pecan industry. An alternative to rootstock selection would be to use pecan cultivars having higher leaf $B$ tolerance. Based on the current results, 'Western' may be able to maintain growth better than 'Wichita' at equivalent leaf B concentrations.

\section{Literature Cited}

Bernstein, L. 1974. Crop growth and salinity, p. 39-53. In: J.V. Schilfgaarde (ed.). Drainage for agriculture. Agron. Ser. 17. Amer. Soc. Agron., Madison, Wis.

Blackmon, G.H. and H.W. Winsor. 1946. Boron uptake in pecans. Proc. Amer. Soc. Hort. Sci. 47:149-152.

Cooper, W.C., A. Peynado, and A.V. Shull. 1955. Boron accumulation in citrus as influenced by rootstock. Rio Grande Valley Hort. Sci. J. 9:8694.

Eaton, F.M. 1935. Boron in soils and irrigation waters and its effect on plants, with particular reference to the San Joaquin Valley of California. U.S. Dept. Agr. Tech. Bul. 448.

Hatcher, J.T. and L.V. Wilcox. 1950. Colorimetric determination of boron using carmine. Anal. Chem. 22:567-569.

Hoagland, D.R. and D.I. Arnon. 1950. The waterculture method for growing plants without soil. Calif. Agr. Expt. Sta. Circ. 347.

Little, T.M. and F.J. Hills. 1978. Agricultural experimentation. Wiley, New York.

Oertli, J.J. and H.C. Kohl. 1961. Some considerations about the tolerance of various plant species to excessive supplies of boron. Soil Sci. 92:243-247.

Raven, J.A. 1980. Short- and long-distance transport of boric acid in plants. New Phytol. 84:231249.

Ryan, J., S. Miyamoto, and J. Stroehlein. 1977. Relation of solute and sorbed boron to the boron hazard in irrigation water. Plant and Soil 47:253256.

Sparks, D. and J.A. Payne. 1976. Bud break in pecan following boron toxicity. HortScience 11:494.

Wilcox, L.V. 1960. Boron injury to plants. U.S. Dept. Agr. Tech. Bul. 211.

U.S. Salinity Laboratory Staff. 1954. Diagnosis and improvement of saline and alkali soils. L.A. Richards (ed.). U.S. Dept. Agr. Hdbk. 60. 